\title{
Ecosystem Services, Sustainable Rural Development and Protected Areas
}

\author{
Mónica de Castro-Pardo ${ }^{1, *}$, João C. Azevedo ${ }^{2}(\mathbb{D})$ and Pascual Fernández ${ }^{3}$ \\ 1 Department of Financial Economics and Actuarial and Statistics-Statistics and Operational Research, Campus \\ of Somosaguas, Complutense University of Madrid, Pozuelo de Alarcón, 28223 Madrid, Spain \\ 2 Centro de Investigação de Montanha, Campus de Santa Apolónia, Instituto Politécnico de Bragança, \\ 5300-253 Bragança, Portugal; jazevedo@ipb.pt \\ 3 Department of Applied Economics I and History and Economic Institutions, UNESCO UNED-URJC Chair in \\ Water and Peace, URJC, Faculty of Law and Social Sciences, Campus of Vicálvaro, Universidad Rey Juan \\ Carlos, Tulipan, Móstoles, 28933 Madrid, Spain; pascual.fernandez@urjc.es \\ * Correspondence: monica.decastro@ucm.es
}

check for updates

Citation: de Castro-Pardo, M.; Azevedo, J.C.; Fernández, P. Ecosystem Services, Sustainable Rural Development and Protected Areas. Land 2021, 10, 1008. https:// doi.org/10.3390/land10101008

Received: 17 September 2021 Accepted: 23 September 2021 Published: 26 September 2021

Publisher's Note: MDPI stays neutral with regard to jurisdictional claims in published maps and institutional affiliations.

Copyright: (c) 2021 by the authors. Licensee MDPI, Basel, Switzerland. This article is an open access article distributed under the terms and conditions of the Creative Commons Attribution (CC BY) license (https:// creativecommons.org/licenses/by/ $4.0 /)$.
Enhancing social and economic development while preserving nature is one of the most significant challenges for humankind in the current century. The Millennium Ecosystem Assessment showed an alarming degradation of ecosystems across the world due to unprecedented changes in land use and ecosystem management driven by human societies in the 20th century [1]. At the same time, poverty and extreme poverty persist in many regions of the world, especially in rural areas, despite programs focused on ecosystems or development and reduction of poverty [2]. Problems related to both ecosystem condition and poverty may be aggravated in the near future if ecosystem destruction and degradation are not reverted. The 2019 Intergovernmental Science-Policy Platform on Biodiversity and Ecosystem Services (IPBES) report [3] highlights the deterioration of ecosystems and the reduction in the supply of ecosystem services worldwide due to increasing pressures and drivers of change in the last 50 years, which have rendered conservation (Aichi Biodiversity Targets) and sustainability (2030 UN Sustainable Development Goals) objectives impossible to achieve unless transformative changes take place in society at both local and global scales.

All the initiatives above and their intrinsic sustainable development models rely on the role of nature as a supporter of ecological functions and provider of ecosystem services. As evidence that drivers of change such as climate and demographics are leading to a worrying increase in environmental risks and decrease in the capability of ecosystems to contribute to well-being, communities across the world are looking for balanced and integrated solutions for growing challenges.

Sustainable rural development is the key to maintaining active local communities in rural and semi-natural areas, avoiding depopulation and preserving sites of high ecological value, including protected areas, and the ecosystem functions and services upon which society relies and that contribute to poverty alleviation both locally and globally.

The establishment of Protected Areas is the oldest and the most commonly applied strategy in biodiversity conservation around the world. Protected areas are core components of conservation infrastructures at national and international levels and contribute strongly to the maintenance of genetic, species and ecosystem diversity as well as the supply of a diverse range of fundamental ecosystem services. The interaction of human communities with protected areas, usually located in rural areas, is complex and often conflictive, although this changes with the categorization as protected areas and the level and economic value of available natural resources. Depending on how they affect access to natural resources and economic opportunities, protected areas can either attract or repel human activities, leading to different development paths. The convergence of development and conservation measures requires, therefore, robust and participative decision-making 
processes that are capable of aligning the needs and expectations of rural communities and the goals of biodiversity conservation. However, the complexity and multi-functionality of rural socioecological systems make decision-making difficult in these areas. It is, therefore, crucial to develop innovative strategies, approaches, methods and models to improve the livelihoods of rural communities and achieve the objectives of nature conservation and sustainable development.

The purpose of this Special Issue was to gather contributions of the scientific community regarding the challenges related to rural development and protected areas, using the concept and application of ecosystem services to support conservation-based development models. It was also a goal of the Special Issue to find directions and guidelines for sustainable rural development, in particular in the context of conservation in natural areas.

This Special Issue includes nine research papers and two review papers. The papers published cover a very wide and diverse geographic area, including studies conducted in national parks in China, in Iceland, a regional park in Spain, a watershed in Costa Rica, the Piedmont Region in Italy, the Taihu Lake in China, the Inner Mongolia region and the Jixi County in China, and the Kapuas Hulu regency in Indonesia. Authors contributing to the Special Issue also come from a wide range of regions and countries, including Chile, China, Costa Rica, Germany, Iceland, Indonesia, Israel, Italy, Portugal, Republic of Korea, Spain, Switzerland and the Netherlands.

The topics covered are very diverse but each brings important contributions to this Special Issue. The concept of ecosystem services and its application have been addressed in the context of land management in national parks and restoration projects [4,5]. He and colleagues [4] analyzed perceptions of ecosystem services and social well-being by residents in the Wuyishan National Park, China, and how these change among groups with different livelihood strategies. Pérez-Rubio et al. [5] developed a micro-scale Payment of Ecosystem Services scheme in southern Costa Rica using primary data generated through spatial modeling and socio-economic and stated preference surveys in the framework of forest ecosystem restoration.

Governance has been addressed in protected areas to test models for expansion of protected areas and in pollinators' conservation policy to support sustainable development [6,7]. In [6], Petursson and Kristofersson analyzed the co-management governance system in the Vatnajökull National Park (VNP), Iceland, providing valuable indications of improvements in a time when there are plans for protected areas to expand in the country. Novelli and co-authors [7] presented and tested a mixed-method tool for use with SWOT analysis to design effective and participative rural development actions in the beekeeping sector in the Piedmont Region, Italy, in the framework of pollinator conservation policy.

The paper by Ibarra-Marinas et al. [8], analyzed an environmental restoration and conservation project in progress in the Regional Park of Las Salinas and Arenales of San Pedro del Pinatar, southeastern Spain, and looked for Natura 2000 network sites for replicating major actions of the project.

Rural areas received attention in this Special Issue from multiple perspectives and in different regions in the world, but one set of papers in particular dealt with sustainability in traditional rural villages and towns, interactions between visitors and rural areas, and economic and ecological effects of agroforestry [9-12]. Kong and colleagues [9] constructed a comprehensive evaluation system for the living protection of traditional villages based on the land-use-integration concept "Production-Living-Ecology", applying it to six traditional villages in Taihu Lake, China. Han and co-authors [10] developed a theoretical framework to explore how cultural contact, natural environment and risk perception affected traveler destination involvement and approach behaviors in the rural tourism sector in Inner Mongolia, China. Additionally, Ren [11] built an indicator system and measurement model for the assessment of rural functions applied to 11 towns in Jixi County, China, to analyze the differentiation characteristics and rules of rural functions (agriculture and nonagricultural production, life and leisure, and ecological functions). Nöldeke and colleagues [12] analyzed the impacts of adopting agroforestry by small farm- 
ers on their livelihoods and the environment in rural Indonesia (Kapuas Hulu regency), which was revealed to be positive, particularly in the context of climate change.

The review papers covered two separate topics. De Castro et al. [13] reviewed the application of Multiple-Criteria Decision-Making (MCDM) approaches to the social, economic and ecological planning and management of water ecosystem services over the 2000-2020 period. Stavi and Yizhaq [14] reviewed the hydrological and geomorphic impacts of mountain biking, highlighting the importance of applying geomorphic principles in the design of singletracks.

The need to align the objectives of local human communities with nature conservation policy and practice is increasingly urgent and vital for the sustainable supply of ecosystem services. The articles compiled in this Special Issue make important contributions to this challenge from different approaches, disciplines and regions in the world, although we expect this topic to remain a research priority for years to come.

Funding: This research received no external funding.

Institutional Review Board Statement: Not applicable.

Informed Consent Statement: Not applicable.

Data Availability Statement: Not applicable.

Acknowledgments: Editors acknowledge the contribution of all authors of the publications in this Special Issue as well as all editors and staff at the journal Land for their collaboration.

Conflicts of Interest: The authors declare no conflict of interest.

\section{References}

1. Millennium Ecosystem Assessment. Ecosystems and Human Well-Being: Current State and Trends; Findings of the Condition and Trends Working Group, Hassan, R., Scholes, R., Ash, N., Eds.; Island Press: Washington, DC, USA, 2005; 948p.

2. Duraiappah, K.A.; Comim, F.; Oliveira, T.; Gupta, J.; Kumar, P.; Pyoos, M.; Spierenburg, M.; Barkin, D.; Brondizio, E.; Tsutsumi, R. Consequences of Responses on Human Well-being and Poverty Reduction. In Millennium Ecosystem Assessment, Ecosystems and Human Well-being: Policy Responses; Findings of the Responses Working Group, Chopra, K., Leemans, R., Kumar, P., Simons, H., Eds.; Island Press: Washington, DC, USA, 2005; pp. 487-526.

3. IPBES. Global Assessment Report on Biodiversity and Ecosystem Services of the Intergovernmental Science-Policy Platform on Biodiversity and Ecosystem Services; Brondizio, E.S., Settele, J., Díaz, S., Ngo, H.T., Eds.; IPBES Secretariat: Bonn, Germany, 2019; 1148p. [CrossRef]

4. He, S.; Gallagher, L.; Min, Q. Examining Linkages among Livelihood Strategies, Ecosystem Services, and Social Well-Being to Improve National Park Management. Land 2021, 10, 823. [CrossRef]

5. Pérez-Rubio, I.; Flores, D.; Vargas, C.; Jiménez, F.; Etxano, I. To What Extent Are Cattle Ranching Landholders Willing to Restore Ecosystem Services? Constructing a Micro-Scale PES Scheme in Southern Costa Rica. Land 2021, 10, 709. [CrossRef]

6. Petursson, J.G.; Kristofersson, D.M. Co-Management of Protected Areas: A Governance System Analysis of Vatnajökull National Park, Iceland. Land 2021, 10, 681. [CrossRef]

7. Novelli, S.; Vercelli, M.; Ferracini, C. An Easy Mixed-Method Analysis Tool to Support Rural Development Strategy DecisionMaking for Beekeeping. Land 2021, 10, 675. [CrossRef]

8. Ibarra-Marinas, D.; Belmonte-Serrato, F.; García-Marín, R.; Ballesteros-Pelegrín, G. Analysis of Replicability of Conservation Actions across Mediterranean Europe. Land 2021, 10, 598. [CrossRef]

9. Kong, L.; Xu, X.; Wang, W.; Wu, J.; Zhang, M. Comprehensive Evaluation and Quantitative Research on the Living Protection of Traditional Villages from the Perspective of "Production-Living-Ecology". Land 2021, 10, 570. [CrossRef]

10. Han, H.; Chen, C.; Ariza-Montes, A.; Hernández-Perlines, F.; Araya-Castillo, L.; Yu, J. Impact of Sustainable Cultural Contact, Natural Atmospherics, and Risk Perception on Rural Destination Involvement and Traveler Behavior in Inner Mongolia. Land 2021, 10, 568. [CrossRef]

11. Ren, K. Following Rural Functions to Classify Rural Sites: An Application in Jixi, Anhui Province, China. Land 2021, 10, 418. [CrossRef]

12. Nöldeke, B.; Winter, E.; Laumonier, Y.; Simamora, T. Simulating Agroforestry Adoption in Rural Indonesia: The Potential of Trees on Farms for Livelihoods and Environment. Land 2021, 10, 385. [CrossRef]

13. de Castro-Pardo, M.; Fernández Martínez, P.; Pérez Zabaleta, A.; Azevedo, J.C. Dealing with Water Conflicts: A Comprehensive Review of MCDM Approaches to Manage Freshwater Ecosystem Services. Land 2021, 10, 469. [CrossRef]

14. Stavi, I.; Yizhaq, H. Applying Geomorphic Principles in the Design of Mountain Biking Singletracks: Conceptual Analysis and Mathematical Modeling. Land 2020, 9, 442. [CrossRef] 